Volume 16, No. 2, Juli 2019

Page: 753- 758

\title{
MANAJEMEN BOTOL SUSU DIPENGARUHI OLEH TINGKAT PENDIDIKAN, PENGETAHUAN DAN SIKAP IBU BAYI/BALITA
}

\author{
Ana Silvia, Rahmawati, Erminawati \\ Poltekkes Kemenkes Banjarmasin Jurusan Kesehatan Lingkungan \\ Jl. H. Mistar Cokrokusumo No.1A Banjarbaru Kalimantan Selatan 70714 \\ E-mail: anasilviaaa16@gmail.com
}

\begin{abstract}
Milk Bottle Management Affected By Level Of Education, Knowledge And Attitude Of Baby/Baby Mother. Management of milk bottles is a maintenance measure for milk bottles. Milk bottle management is a personal management that is carried out individually by mothers. Deficiencies in milk bottle management can be influenced by the level of education, knowledge, and attitude of a person. The purpose of this study was to determine the relationship of education, knowledge, and attitude with the management of milk bottles by mothers in Kelurahan Cempaka. The type of this research was analytic survey with cross sectional design. The sample in this study were mothers who had babies or toddlers using milk bottles in the provision of drinks totaling 96 mothers. The sampling technique used Purposive sampling. Data analyzed using the Spearman test. The results showed that there was a relationship between education and milk bottle mangement ( $p 0.007<\alpha$ 0.05), there was a correlation between knowledge about the use of milk bottles and milk bottle management ( $p 0,000<\alpha 0,05)$, and there was a relationship between use of milk bottle management ( $p 0.024<\alpha 0.05$ ). To the sanitarian of the public health center, they can provide counseling to mothers who use milk bottles in the provision of drinks about the management of milk bottles in Kelurahan Cempaka.
\end{abstract}

Keywords: Management; Milk Bottle; Relationship

\begin{abstract}
Abstrak: Manajemen Botol Susu Dipengaruhi Oleh Tingkat Pendidikan, Pengetahuan Dan Sikap Ibu Bayi/Balita. Manajemen botol susu adalah tindakan pemeliharaan botol susu. Manajemen botol susu merupakan manajemen pribadi yang dilakukan secara individu oleh ibu. Kekurangan pada manajemen botol susu dapat dipengaruhi oleh tingkat pendidikan, pengetahuan, dan sikap seseorang. Penelitian ini bertujuan adalah mengetahui hubungan pendidikan, pengetahuan, dan sikap dengan manajemen botol susu oleh ibu di Kelurahan Cempaka. Jenis penelitian ini adalah survey analitik dengan desain cross sectional. Sampel dalam penelitian ini adalah ibu yang memiliki bayi atau balita menggunakan botol susu dalam pemberian minuman berjumlah 96 ibu. Tekhnik pengambilan sampel menggunakan Purposive sampling. Analisis data menggunakan uji Spearman. Hasil penelitian menunjukkan ada hubungan pendidikan dengan manajemen botol susu $(p 0,007<\alpha 0,05)$, ada hubungan pengetahuan tentang penggunaan botol susu dengan manajemen botol susu ( $p 0,000<\alpha 0,05)$, dan ada hubungan sikap penggunaan dengan manajemen botol susu ( $p 0,024<\alpha 0,05)$. Kepada sanitarian puskesmas dapat memberi penyuluhan kepada ibu-ibu yang menggunakan botol susu dalam pemberian minuman tentang manajemen botol susu di Kelurahan Cempaka.
\end{abstract}

Kata kunci: Botol Susu; Hubungan; Manajemen

\section{PENDAHULUAN}

Badan Penelitian dan Pengembangan Kesehatan telah menyelesaikan Riset Kesehatan Dasar (Riskesdas) 2018 yang dilakukan secara terintegrasi dengan Susenas pada bulan Maret (Badan Pusat Stastistik). Prevalensi penyakit menular seperti ISPA, malaria, dan diare pada balita mengalami penurunan jika dibandingkan dengan hasil Riskesdas 2013. Prevalensi penyakit diare pada balita turun dari $18,5 \%$ menjadi $12,3 \%{ }^{[1]}$.

Diantara banyak macam gangguan saluran cerna, diare memang merupakan salah satu yang paling sering terjadi pada bayi dan anak. Banyak faktor yang dapat 
menyebabkan kejadian diare pada balita seperti adanya infeksi yang disebabkan bakteri, virus dan parastit atau adanya gangguan absorbsi makanan pada usus (malabsorbsi), alergi, keracunan bahan kimia atau adanya racun yang terkandung dalam makanan maupun minuman. Faktor terjadinya diare akut pada balita antara lain faktor lingkungan, tingkat pengetahuan ibu, sosial ekonomi masyarakat dan makanan atau minuman yang dikonsumsi. Pada usia bayi dan balita lebih banyak diberikan minuman berupa ASI dan susu formula. Tidak hanya itu kebersihan wadah dalam pemberian susu juga harus diperhatikan[2].

Di Kota Banjarbaru pada bulan januari sampai dengan bulan juni tahun 2018 terdapat 671 kasus diare pada bayi dan balita. Wilayah kerja Puskesmas Rawat Inap Cempaka yang paling tinggi kasus diarenya dengan jumlah 157 kasus dengan dominan balita pada umur 1 sampai 4 tahun. Berdasarkan data pada bulan juli sampai september Kelurahan Cempaka yang merupakan salah satu wilayah kerja Puskesmas Rawat Inap Cempaka paling tinggi kasus diare dengan jumlah 78 kasus.

Berdasarkan hasil studi pendahuluan yang dilakukan peneliti di Kelurahan Cempaka dari 15 ibu yang diwawancarai, 12 dari 15 ibu menggunakan botol susu sebagai wadah dalam pemberian minuman kepada bayi dan balitanya. Dari 12 ibu tersebut terdapat 6 ibu yang menggunakan sabun khusus botol bayi untuk pencucian dan hanya 3 ibu yang melakukan pensterilan botol susu satu kali seminggu. Dari $12 \mathrm{ibu}$, 8 ibu tersebut tidak mengetahui bagaimana cara memilih botol yang aman yang sudah tertera dibawah botol tanda bahan botol, kandungan BPA, dan lainnya.

\section{BAHAN DAN CARA PENELITIAN}

Jenis penelitian yang digunakan adalah survey analitik dengan desain penelitian cross sectional. Populasi penelitian ini adalah seluruh ibu di Kelurahan Cempaka yang memiliki bayi dan balita. Sampel penelitian berjumlah 96 ibu yang memiliki anak berkisar umur 1 sampai 4 tahun. Pengambilan sampel menggunakan tekhnik purposive sampling. Penelitian ini dilakukan di Kelurahan Cempaka. Penelitian ini dilaksanakan dari bulan November 2018 sampai Mei 2019. Variabel bebas dalam penelitian ini adalah tingkat pendidikan, pengetahuan dan sikap yang memiliki bayi dan balita, serta manajemen botol susu oleh ibu sebagai variabel terikat.

Analisis univariat dilakukan untuk mendeskripsikan atau menjabarkan masing-masing variabel. Analisis bivariat dilakukan untuk melihat hubungan antara variabel independen dengan dependen menggunakan uji statistik Korelasi Spearman.

\section{HASIL PENELITIAN DAN PEMBAHASAN}

Hasil distribusi data ibu di Kelurahan Cempaka

Tabel 1. Distribusi Responden Berdasarkan Umur

\begin{tabular}{ccc}
\hline Umur Ibu & Frekuensi & $\%$ \\
\hline $19-27$ tahun & 46 & 48 \\
$28-35$ tahun & 41 & 43 \\
$36-44$ tahun & 9 & 9 \\
Total & 96 & 100 \\
\hline
\end{tabular}

Berdasarkan tabel 1. diketahui bahwa umur ibu yang menjadi responden dominan memiliki umur 19 sampai 27 tahun berjumlah 46 ibu (48\%). 
Tabel 2. Distribusi Responden Berdasarkan Pekerjaan

\begin{tabular}{lcc}
\hline \multicolumn{1}{c}{ Pekerjaan Ibu } & Frekuensi & $\%$ \\
\hline Ibu Rumah Tangga & 91 & 95 \\
Pedagang & 1 & 1 \\
Pegawai Swasta & 2 & 2 \\
PNS $\quad 2$ & 2 \\
\multicolumn{1}{c}{ Total } & 96 & 100 \\
\hline
\end{tabular}

Berdasarkan tabel 2. diketahui memiliki mayoritas pekerjaan sebagai ibu rumah tangga dengan jumlah $91 \mathrm{ibu}$ $(95 \%)$.

Tabel 3. Distribusi Manajemen Botol Susu

\begin{tabular}{lccc}
\hline \multicolumn{2}{r}{ Manajemen } & Frekuensi & $\%$ \\
\hline Baik & 36 & 38 \\
Cukup & 46 & 48 \\
Kurang & 14 & 14 \\
\multicolumn{2}{r}{ Total } & 96 & 100 \\
\hline
\end{tabular}

Berdasarkan tabel 3. diketahui manajemen yang cukup berjumlah $46 \mathrm{ibu}$ bahwa manajemen botol susu oleh ibu di Kelurahan Cempaka dominan memiliki $(48 \%)$.

Tabel 4. Distribusi Pelaksanaan Manajemen Botol Susu

\begin{tabular}{lccccccc}
\hline \multirow{2}{*}{ Manajemen botol susu } & \multicolumn{3}{c}{ Pelaksanaan } \\
& \multicolumn{2}{c}{ Baik } & \multicolumn{2}{c}{ Cukup } & \multicolumn{2}{c}{ Kurang } \\
& $\mathrm{F}$ & $\%$ & $\mathrm{~F}$ & $\%$ & $\mathrm{~F}$ & $\%$ \\
\hline Pemilihan botol susu & 3 & 3 & 17 & 18 & 76 & 79 \\
Pemakaian botol susu & 82 & 85 & 14 & 15 & 0 & 0 \\
Pencucian botol & 56 & 58 & 20 & 21 & 20 & 21 \\
Pensterilan botol & 3 & 3 & 17 & 18 & 76 & 79 \\
Lama penggunaan & 48 & 50 & 28 & 29 & 20 & 21 \\
\hline
\end{tabular}

Berdasarkan tabel 4 dapat dilihat bahwa pelaksaan manajemen botol susu yang kurang terdapat pada pelaksanaan pemilihahan botol susu dengan persentase $79 \%$ dan pensterilan botol susu dengan persentase $79 \%$.

Tabel 5. Distribusi Manajemen Botol Susu Berdasarkan Tingkat Pendidikan

\begin{tabular}{|c|c|c|c|c|c|c|c|c|}
\hline \multirow{3}{*}{ Pendidikan } & \multicolumn{8}{|c|}{ Manajemen } \\
\hline & \multicolumn{2}{|c|}{ Baik } & \multicolumn{2}{|c|}{ Cukup } & \multicolumn{2}{|c|}{ Kurang } & \multicolumn{2}{|c|}{ Total } \\
\hline & $\mathrm{F}$ & $\%$ & $\mathrm{~F}$ & $\%$ & $\mathrm{~F}$ & $\%$ & $\mathrm{~F}$ & $\%$ \\
\hline Perguruan Tinggi & 4 & 4 & 0 & 0 & 0 & 0 & 4 & 4 \\
\hline SMA & 13 & 14 & 13 & 14 & 3 & 3 & 29 & 30 \\
\hline SMP & 18 & 19 & 16 & 16 & 10 & 10 & 44 & 46 \\
\hline SD & 1 & 1 & 17 & 18 & 1 & 1 & 19 & 20 \\
\hline Total & 36 & 38 & 46 & 48 & 14 & 14 & 96 & 100 \\
\hline
\end{tabular}

Berdasarkan tabel 5. dapat diketahui ibu dengan pendidikan perguruan tinggi semuanya memiliki manajemen botol susu baik sebanyak $4 \mathrm{ibu}$ (4\%), sedangkan ibu dengan pendidikan SD lebih banyak memiliki manajemen botol susu cukup sebanyak 17 ibu (18\%).
Hasil uji statistik dilakukan dengan menggunakan uji Spearman didapatkan nilai p $0,007<\alpha 0,05$ yang berarti secara statistik ada hubungan antara tingkat pendidikan dengan manajemen botol susu. Nilai kekuatan korelasi sebesar 0,273 
menunjukkan kekuatan korelasi lemah dan korelasi searah.

Tabel 6. Distribusi Manajemen Botol Susu Berdasarkan Pengetahuan

\begin{tabular}{lrrrrrrrc}
\hline \multirow{2}{*}{ Pengetahuan } & \multicolumn{9}{c}{ Baik } & \multicolumn{1}{c}{ Cukup } & \multicolumn{2}{c}{ Kurang } & \multicolumn{2}{c}{ Total } \\
& F & $\%$ & F & $\%$ & F & $\%$ & F & $\%$ \\
\hline Baik & 34 & 35 & 25 & 26 & 0 & 0 & 59 & 62 \\
Cukup & 2 & 3 & 16 & 17 & 9 & 9 & 27 & 28 \\
Kurang & 0 & 0 & 5 & 5 & 5 & 5 & 10 & 10 \\
$\quad$ Total & 36 & 38 & 46 & 48 & 14 & 14 & 96 & 100 \\
\hline
\end{tabular}

Berdasarkan tabel 6. dapat diketahui ibu sebagai reponden yang mempunyai pengetahuan baik tidak ada yang memiliki manajemen botol susu kurang, sedangkan ibu yang mempunyai pengetahuan kurang tidak ada yang memiliki manajemen botol susu baik. Hasil uji statistik dilakukan dengan menggunakan uji Spearman didapatkan nilai p $0,000<\alpha 0,05$ yang berarti secara statistik ada hubungan antara pengetahuan dengan manajemen botol susu. Nilai kekuatan korelasi sebesar 0.634 menunjukkan kekuatan korelasi kuat dan memiliki arah kolerasi yang searah.

Tabel 7. Distribusi Manajemen Botol Susu Berdasarkan Sikap Penggunaan

\begin{tabular}{lrrrrrrrr}
\hline \multirow{1}{*}{ Sikap } & \multicolumn{1}{c}{ Manajemen } \\
& \multicolumn{1}{c}{ Baik } & \multicolumn{1}{c}{ Cukup } & \multicolumn{2}{c}{ Kurang } & \multicolumn{2}{c}{ Total } \\
& F & $\%$ & F & $\%$ & F & $\%$ & F & $\%$ \\
\hline Positif & 34 & 36 & 37 & 39 & 10 & 10 & 81 & 84 \\
Negatif & 2 & 2 & 9 & 9 & 4 & 4 & 15 & 16 \\
$\quad$ Total & 36 & 38 & 46 & 48 & 14 & 14 & 96 & 100 \\
\hline
\end{tabular}

Berdasarkan tabel 7. dapat diketahui bahwa ibu memiliki sikap yang positif dominan memiliki manajemen botol susu yang cukup sebanyak $37 \mathrm{ibu}$ (39\%), dan ibu yang memiliki sikap negatif juga memiliki dominan manajemen botol susu yang cukup sebanyak 9 ibu (9\%). Hasil uji statistik

Hasil uji statistik dilakukan dengan menggunakan uji Spearman didapatkan nilai p $0,007<\alpha 0,05$ yang berarti secara statistik ada hubungan antara tingkat pendidikan dengan manajemen botol susu. Nilai kekuatan korelasi sebesar 0,273 menunjukkan kekuatan korelasi lemah dan korelasi yang searah. Ibu-ibu di Kelurahan Cempaka lebih banyak memiliki pendidikan SMP, hal ini dikarenakan pola pikir masyarakat yang beranggapan bahwa perempuan tidak perlu memiliki tingkat pendidikan yang tinggi dan perempuan tidak perlu bekerja cukup menjadi ibu rumah tangga. Selain itu, letak Sekolah Menengah Atas yang berjarak cukup jauh dari pemukiman. Pendidikan itu dilakukan dengan menggunakan uji Spearman didapatkan nilai p 0,024< $\alpha 0,05$ yang berarti secara statistik ada hubungan antara sikap dengan manajemen botol susu. Nilai kekuatan korelasi sebesar 0.230 menunjukkan kekuatan korelasi lemah dan memiliki arah kolerasi yang searah.

menentukan manusia untuk berbuat dan mengisi kehidupannya untuk mencapai keselamatan dan kebahagiaan. Semakin tinggi tingkat pendidikan seseorang, maka akan mudah menerima informasi sehingga semakin banyak pula menerima pengetahuan yang dimilikinya. Sebaliknya pendidikan yang kurang akan menghambat perkembangan sikap seseorang terhadap nilai-nilai baru yang diperkenalkan ${ }^{(3)}$. Hasil uji statistik dilakukan dengan menggunakan uji Spearman didapatkan nilai p $0,000<\alpha 0,05$ yang berarti secara statistik ada hubungan antara tingkat pengetahuan dengan manajemen botol susu. Nilai kekuatan korelasi sebesar 0.634 menunjukkan kekuatan korelasi kuat dan 
memiliki arah kolerasi yang searah. Semakin tinggi tingkat pengetahuan semakin baik manajemen botol susu yang dilakukan oleh ibu. Hal ini dibuktikan ibu yang memiliki manajemen botol susu baik didominasi oleh ibu yang berpengetahuan tinggi sebanyak 34 ibu (35\%). Ibu yang memiliki pengetahuan baik namun manajemen botol susu nya cukup dan pengetahuan sedang namun manajemen botol susu nya kurang ini dapat disebabkan oleh ketidaktahuan tentang pemilihan bahan botol susu yang benar dan waktu sterilisasi yang diketahui oleh kebanyakan ibu di Kelurahan Cempaka hanya 5 menit. Seharusnya ibu memilih botol yang aman dan menghindari penggunaan botol yang mengandung Bisphenol-A (BPA). Paparan BPA terhadap anak menimbulkan beberapa masalah kesehatan seperti gangguan hormon, sistem reproduksi, saraf, dan sistem daya tahan tubuh yang berpengaruh pada proses perkembangan anak. Botol yang aman adalah botol dengan lambang \#2 HDPE, \#4 LDPE, \#5 PP, food grade, BPA Free. Waktu sterilisasi yang dianjurkan yaitu \pm 15 menit.Adapun faktor lain yang mempengaruhi pengetahuan yaitu pengalaman, pendidikan, dan umur. Pengalaman bisa jadi dikaitkan dengan jumlah anak, dimana ibu yang sudah memiliki anak sebelumnya lebih berpengalaman dibanding ibu yang hanya memiliki anak satu. Semakin tinggi tingkat pendidikan seseorang, maka akan mudah menerima informasi sehingga semakin banyak pula menerima pengetahuan yang dimilikinya. Semakin cukup umur, tingkat kematangan dan kekuatan seseorang akan lebih matang dalam berfikir dan bekerja. Hasil uji statistik dilakukan dengan menggunakan uji Spearman didapatkan nilai p 0,024 $<\alpha 0,05$ yang berarti secara statistik ada hubungan antara sikap dengan manajemen botol susu. Nilai kekuatan korelasi sebesar 0.230 menunjukkan kekuatan korelasi lemah dan memiliki arah kolerasi yang searah. Adanya ibu yang memiliki sikap positif namun manajemen botol susunya adalah kurang ini dapat disebabkan oleh kurangnya rasa bertanggung jawab yang merupakan sikap paling tinggi dalam tingkatan sikap. Ibu yang memiliki sikap negatif namun manajemen botol susunya adalah baik ini dapat disebabkan oleh kecenderungan dalam bertindak (end to behave) yang merupakan salah satu komponen pokok sikap(4). Ibu di Kelurahan Cempaka banyak tidak setuju tentang melihat tanda label yang terdapat pada botol merupakan hal yang penting sebelum membeli, hal ini dikarenakan ibu beranggapan semua botol susu itu sama saja. Tanda pada botol merupakan sebuah petunjuk tentang bahan botol, keamanan dalam perebusan botol, dan kandungan BPA dalam botol. Dampak negatif dari botol yang tidak aman adalah gangguan kesehatan seperti kanker dan gangguan hormon.

\section{KESIMPULAN DAN SARAN}

Berdasarkan hasil dan pembahasan didapatkan hasil bahwa ada hubungan antara tingkat pendidikan dengan manajemen botol susu (nilai p 0,007 < $0,05)$, ada hubungan antara pengetahuan dengan manajemen botol susu (nilai $p$ $0,000<0,05$ ), ada hubungan antara sikap dengan manajemen botol susu (nilai $p$ $0,024<0,05$ ).

Saran yang dapat diberikan kepada sanitarian puskesmas memberikan penyuluhan kepada ibu-ibu yang menggunakan botol tentang manajemen botol susu.

\section{KEPUSTAKAAN}

1. Riskesdas. (2018). Potret Sehat Indonesia dari Riskesdas 2018. Retrieved from Kementrian Kesehatan Republik Indonesia: http://www.depkes.go.id/article/view /18110200003/potret-sehatindonesia-dari-riskesdas-2018.html

2. Rachmawati, A. R. (2017). 31,4 Persen Kematian Bayi karena Diare. Retrieved januari 30, 2019, from https://www.pikiranrakyat.com/nasional/2017/12/13/31 4-persen-kematian-bayi-karena-diare415805

3. Nursalam, \& Pariani. (2008). Konsep dan Penerapan Metodologi Penelitian Ilmi Keperawatan. Jakarta: Salemba Medika. 
4. Notoatmodjo, S. (2007). Promosi Kesehatan dan Ilmu Perilaku. Jakarta Rineka Cipta 